to all vegetables. He observed that neither the odours of the fresh, dried, and burnt sponges, nor the presence of ammonia in them, afforded proofs of their animality, and that there really is no more peculiarity in their chemical composition than what likewise exists in that of certain plants.

Mr. Hogg therefore maintains it to be impossible to account the Spongilla as belonging to the vegetable kingdom and the Spongia to the animal ; and since he has become sure of the former, and since the Spongia is now known to possess neither one organ nor a single property peculiar to an animal, he has been at length forced to acknowledge the vegetable nature of the Spongia.

Moreover, the fact of Dr. Grant having witnessed the locomotive sporules of some of the sea sponges germinating and developing themselves after the forms of their parent structures, at once decides that they cannot be the nidus or matrix, or the fabrication or production of any marine animal.

Lastly, Mr. Hogg, considering to what order of plants the freshwater and the sea sponges should be referred, proposed to classify them in a separate order "Spongix," which ought to be placed between the order Fungi and that of the Algæ.

\title{
MISCELLANEOUS.
}

ON THE STRUCTURE OF THE VOLVOCINAE.

M. Ehrenberg observes, "that with respect to the organization of the genus Volvox, all endeavours to acquire some knowleảge of it have only proved successful, now that observation has been at last directed to the right depth (1833). Formerly the entire globule was generally regarded as a single verrucose or ciliated animalcule, and its bursting considered as the reproduction of simple individuals. But this view leads to wonders and to contradictions; it is evidently erroneous, and the organic relations lie much deeper. Each globule is a hollow monadier (Monadenstock) of many hundreds, nay, thousands of minute animalcules; and within this, several smaller globules are developed, which however are not single individuals, but also Monadiers. The single animals are those small greenish warts or points on the surface, and they resemble the Monads. Each animalcule bears precisely the same relation as a single animal of Gonium pectorale; it possesses a gelatinous shield open anteriorly, which when full-grown it can leave, and is connected by three to six thread-like tubes with the neighbouring individuals. It is evi- 
dently then quite erroneous to compare the green bodies of Gonium or of Pandorina with the larger inner globules of Volvox; they are to be compared with the minute outer granules on the surface : and though Volvox is much larger than Gonium in its aggregate state, yet the individual animals are much smaller. In these small animalcules, which appear in the form of very minute green warts on the periphery of the Volvox-globule, and to which little attention has hitherto been paid, I have succeeded, by a laborious research, in recognising relations of structure which coincide entirely with those peculiar to the family of Monads."

For the details of structure of these highly interesting Infusoria we must refer the reader to Ehrenberg's work, ' Ueber die Infusionsthierchen', whence this extract is taken; and we may merely state that this illustrious naturalist succeeded in discovering nutritive organs, mouth, eyes, generative organs, \&c.

\section{DEVELOPMENT OF THE LEGUMINOSAE.}

Drs. Schleiden and Vogel draw from their interesting observations on the development of this large family of plants published in the 'Acta Acad. C. L. C. Nat. Cur.' vol. xix. p. 1. the following conclusions :

1. The flowers of the Leguminosa are at their origin perfectly regular.

2. The subsequently cohering parts originate as free points, are developed free, and cohere subsequently.

3. All the parts of the flower are at their first appearance green leaves.

4. Even in the earliest stage only one carpellary leaf is visible in the Leguminosa, which is open in the direction of the axis.

5. The anthers are formed from leaves, the inner cellular tissue being converted in part into pollen; and the loculi originate at both sides of the margin of the leaf, which is subsequently changed into the bursting rima.

6. The ovules are formed alternately at the upper margin of the ovarium, and consist of the nucleus and generally of two integuments, rarely of an integumentum simplex.

7. The ovules of the Papilionacea are hemitropous.

8. The embryo originates from the pollen tube at the micropyle end of the embryonal sac, and increases either from this place towards the chalaza, or (being propelled by the pollen tube, which has become cellular, to the centre of the embryonal sac), both in the direction of the chalaza and that of the micropyle. 
9. The epidermis of the seed is formed in the Leguminosa only of one integument, which, however, always separates into several layers.

10. No endopleura tumida exists in the Leguminosa ; what has been considered as such is albumen, and in fact endosperm.

The authors have also discovered that the ovules of the genus $\mathrm{Lu}$ pinus are only provided with a simple integument, while those of the other Leguminosa always possess a double one.

ON THE STRUCTURE OF THE SCALES OF FISH AND REPTILES.

M. Mandl, in a memoir presented to the French Academy, states that the scales are composed of a superior and of an inferior layer. The upper layer is composed, $a$. of longitudinal canals, proceeding in the form of longitudinal lines, from a point which is not always the centre of the scale; $b$. of cellular lines, i. e. of lines in which he thought he perceived the margins of successive layers of increase, but which, according to his observations, were nothing more than lines produced by the union or fusion of cells; $c$. of yellow corpuscles analogous to the corpuscles of bones, and of cartilages containing salts like them; $d$. of a focus occupied by interrupted cellular lines, by imperfect cells and corpuscles, \&c. : the focus appears to be the first rudiment of the scale; $e$. of the teeth of the scale, which exist only on the terminal margin in the Acanthopterygians and are wanting in the Malacopterygians.

The inferior layer is composed of fibrous lamellæ, of which the outer ones are the longest. The elements of the fibrous layers, which in hard scales frequently shine through the superior layer, may be isolated by rupture.

The author concludes from his observations that the scales cannot be regarded as simple products of secretion, but that a true organization must be admitted in them. M. Mandl also considers with M. Agassiz that the scales may serve as characters in classification. -Comptes Rendus, June 24, 1839.

\section{LEMNA ARRHIZA.}

J. F. Hoffmann has instituted a series of observations to prove that Lemna arrhiza is a constant species; he observed the plant for two years separated from all foreign mixture, and never saw individuals produced which were of a different species. He also observed for several years the other common species of Lemna, and never found anything that could be compared to $L$. arrhiza, nor have any intermediate forms been discovered.-Tijdschrift $v$. naturl. Geschiedenis en Physiol. iv. p. 282. 
DISCOVERY OF MUMMIES AT DURANGO, MEXICO.

A million of mummies have lately been discovered near Durango, in Mexico. They are in a sitting posture, but have the same wrappings, bands, and ornaments as the Egyptians; among them was found a poignard of flint, with a sculptured handle, chaplets, necklaces, \&c., of alternately coloured beads, fragments of bones polished like ivory, fine worked elastic tissues, moccasins worked like those of our Indians, bones of vipers, \&c. A fact of importance is stated; that the necklaces are of a marine shell found at Zacatecas, on the Pacific, where the Columbus of their forefathers probably therefore landed from Hindostan or from the Malay, or Chinese coast, or from their islands in the Indian ocean.-Silliman's American Journal, April, 1839.

\section{EXPERIMENTS ON THE OLFACTORY SENSE OF THE ANTENNÆ. BY}

M. A. LEFEBVRE.

The observations of the author were first made upon a bee which was feeding upon a piece of sugar. Having moistened a long needle with æther, he approached it gently to the sugar; but the extremity of the instrument had hardly come within a few lines of the insect when it showed great uneasiness, and did not cease agitating its antennæ whilst directing them towards the odorous body. The bee, on the contrary, was not at all affected when M. Lefebvre touched the piece of sugar with a needle which had not been dipped in æther, or with a match, \&c. "After having given the insect some moments of rest," says the author, "I again plunged my needle into the æther, and, hoping to accustom it to this penetrating smell, I approached the needle softly to its anal extremity. The bee did not move, but continued eating. Encouraged by this success, I slid the point of my needle along the body against the feet, but without touching the stigmata; I even deposited a little drop of the liquid there, and I did all this without the bee's appearing in the least uneasy. My surprise was very great to see that the insect suffered nothing in the neighbourhood of the stigmata, but as soon as I sought to pass the fore feet, the antennæ, by being lowered, obstructed my progress.

"I began again, and in advancing along the back from the hinder to the fore part, there was the same immoveableness as long as I went no further than the abdomen; but as soon as I arrived above the thorax the antennæ were suddenly thrown over, agitated and trembling with anger." M. Lefebvre subsequently made some experiments on wasps; he cut off the antennæ of these insects at different lengths, and made himself sure by means of æther, that a slight section at the extremity of these organs is sufficient to produce 
a more or less complete loss of smell. The deprivation of the last joint of the antennæ suffices to cause the loss of this sense.-Extract from the Annales de la Société Entomologique de France, 1838, 3rd Part.

\section{GEOGRAPHICAL DISTRIBUTION OF PALMS.}

M. v. Martius has published an elaborate treatise on the geographical distribution of palms, which he divides into five groups, viz. Arecince, Lepidocaryina, Borassince, Coryphina, and Coccina. The distribution of the palms with which we are at present acquainted is as follows :

\begin{tabular}{|c|c|c|c|}
\hline Arecince & $\begin{array}{l}\text { Old World. } \\
53\end{array}$ & $\begin{array}{c}\text { New World. } \\
45\end{array}$ & $\begin{array}{c}\text { Total. } \\
98\end{array}$ \\
\hline Lepidocaryina... & 60 & 7 & 67 \\
\hline Borassine ..... & 11 & 24 & 35 \\
\hline Coryphina & 33 & 24 & 57 \\
\hline Coccince... & 2 & 99 & 101 \\
\hline & 159 & 199 & 358 \\
\hline
\end{tabular}

Of these 358 palms Europe contains 1, New Holland 6, New Zealand 1, Oceania 2, Africa 13, Asia 131, and America 198.

\section{METEOROLOGICAL OBSERVATIONS FOR JUNE, 1839.}

Chiswick.-June 1. Overcast: fine. 2. Dry haze. 3. Foggy : rain. 4. Foggy : cloudy. 5. Very fine : heavy rain at night. 6. Very fine. 7. Rain. 8-13. Very fine. 14-15. Hazy. 16. Very fine. 17. Very fine: thunder at night. 18. Slight haze : cloudy, with thunder. 19. Very fine : lightning at night. 20. Very hot. 21. Cloudy and fine. 22. Showery. 23. Stormy with rain. 24. Cloudy. 25. Very fine : rain. 26. Sultry : thunder. 27. Fine. 28. Thunder showers. 29, 30. Cloudy and cold.

Boston.-June 1,2. Cloudy. 3. Rain: rain early A.M. 4, 5. Cloudy. 6. Fine: $30^{\prime}$ clock p.M. therm. $72^{\circ}$. 7. Cloudy : rain P.M. 8-10. Fine. 11. Cloudy. 12. Fine. 13. Cloudy : rain P.M. 14. Rain : heavy rain with lightning early A.M. : rain again A.M. and P.M. 15-17. Cloudy. 18-20. Fine. 21. Cloudy : rain early A.M. 22. Fine : rain A.M. and P.M. 23. Cloudy : rain P.M. 24. Fine : rain early A.m. 25. Fine. 26. Rain. 27. Cloudy; rain r.M., with clap of thunder. 28. Rain. 29. Cloudy : rain P.M. S0. Cloudy.

I. Applegarth Manse, Dumfries-shire.-June 1,2. Dry and withering. 3. Getting cloudy. 4. Very warm: air electrical. 5. Cleared up: soft and warm. 6. Pleasant day : moderate breeze. 7. Gentle rain all day. 8. Fair and droughty. 9. Fine day, but parching. 10. A welcome rain p.м. 11. Fine growing day: ground refreshed. 12. Genial rain: vegetation strong. 13. Rather cool A.M. : rain P.M. 14. Fair : growing day. 15, 16. Very warm and genial. 17. The same : thunder and rain P.M. 18. Very warm, but getting cloudy. 19. The same: rain P.M. 20. The same: getting cloudy. 21. Rain nearly all day. 22. Rain, soft and genial. 23. Showery all day. 24. Dull day, but kept dry. 25. Fine summer day. 26. Cloudy morning : cleared up. 27. Thunder, with heavy showers. 28, 29. Fair : temperature cool. 30. Beautiful summer day.

Sun shone out 26 days. Rain fell 10 days. Thunder 2 days. days.

Wind southerly 12 days. Westerly 6 days. Easterly 6 days. Northerly 6

Calm weather 9 days. Moderate 12 days. Brisk 8 days. Boisterous 1 day. Ann. Nat. Hist. Vol, 3. No.20. Aug. $1839 . \quad 2$ ц 
ว.ा!प

-sวțjuing

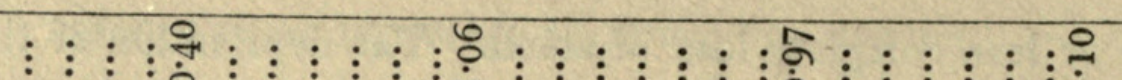

ก

นuo7sog |

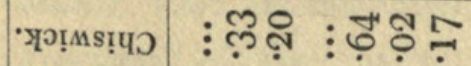

हुं

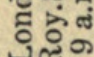

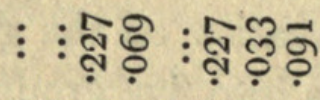

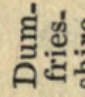

嘋

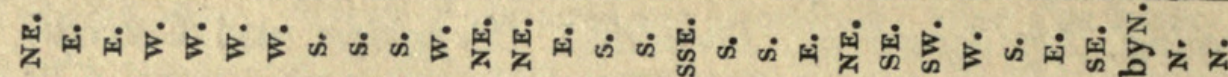
岕 宕 范 घี घี घี घี

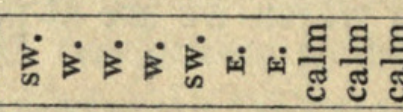

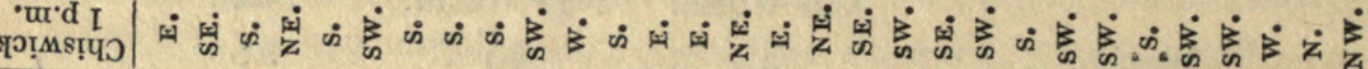

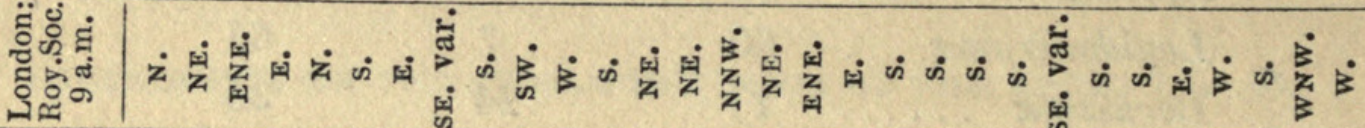

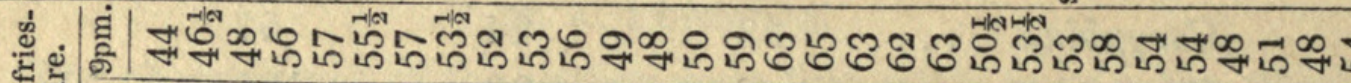

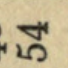

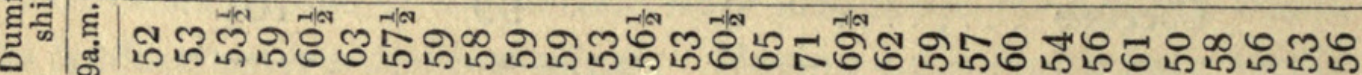

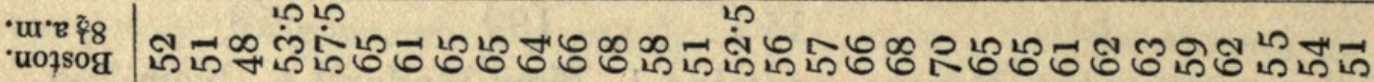

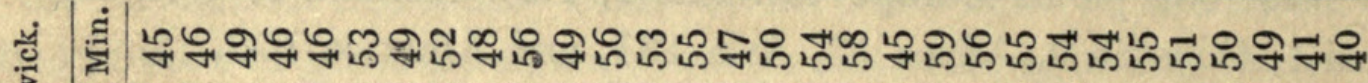

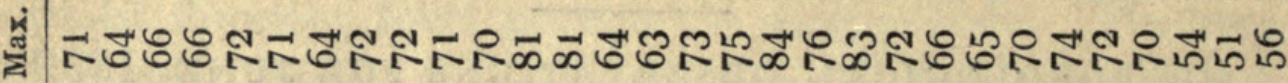

-

๒

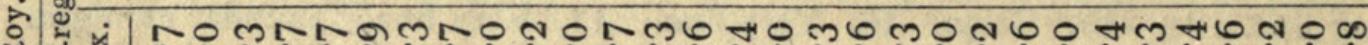

ت

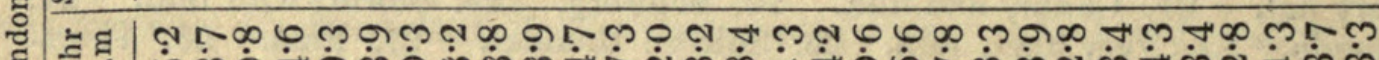

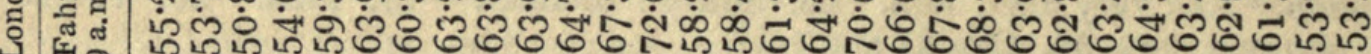

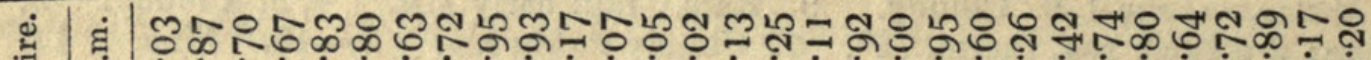
ज

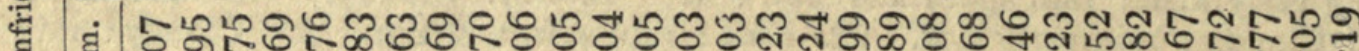

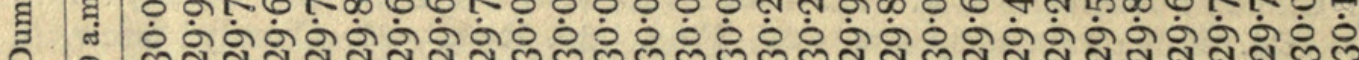

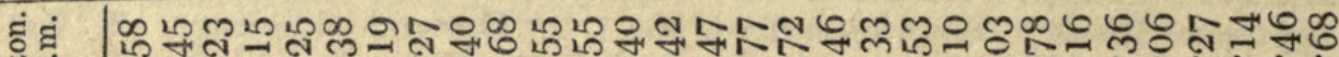

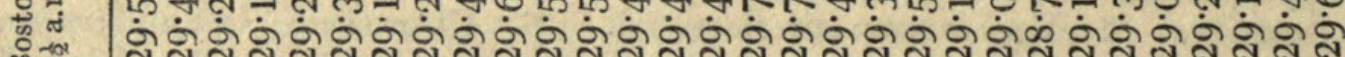

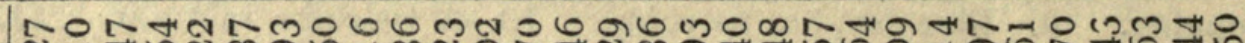

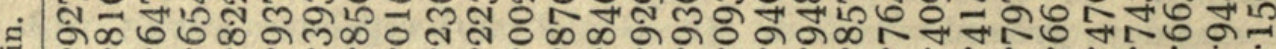

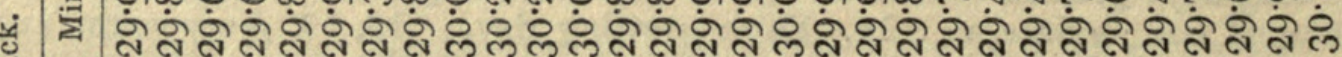

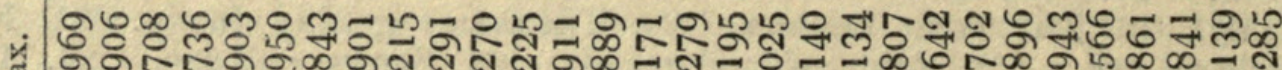

สิ்่ कें

范

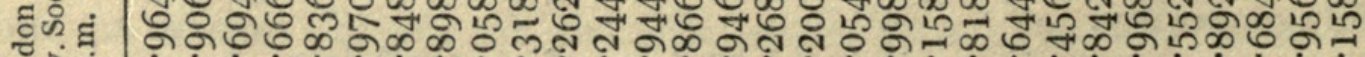

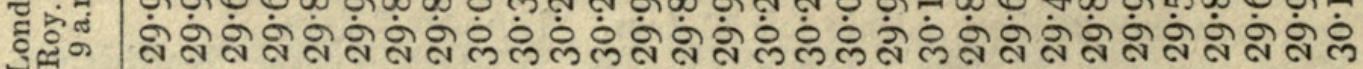

Tor




\section{$2 \mathrm{BHL}$ Biodiversity Heritage Library}

1839. "Miscellaneous." Annals of natural history 3, 461-466.

https://doi.org/10.1080/03745483909443263.

View This Item Online: https://www.biodiversitylibrary.org/item/19627

DOI: https://doi.org/10.1080/03745483909443263

Permalink: https://www.biodiversitylibrary.org/partpdf/35117

\section{Holding Institution}

Natural History Museum Library, London

\section{Sponsored by}

Natural History Museum Library, London

\section{Copyright \& Reuse}

Copyright Status: NOT_IN_COPYRIGHT

This document was created from content at the Biodiversity Heritage Library, the world's largest open access digital library for biodiversity literature and archives. Visit BHL at https://www.biodiversitylibrary.org. 